\title{
Hemodinâmica do vasoespasmo
}

\author{
Marcos Augusto Stávale Joaquim', Gustavo Cartaxo Patriota ${ }^{1}$, André de Macedo Bianco² \\ Instituto de Neurociências, São Paulo, SP. \\ Serviço de Neurocirurgia Hospital Nove de Julho, São Paulo, SP.
}

\section{RESUMO}

Os autores descrevem as alterações hemodinâmicas encefálicas que ocorrem na vigência do vasoespasmo após a hemorragia subaracnoidea por aneurismas. O conhecimento dessas alterações facilita o entendimento das medidas terapêuticas.

\section{PALAVRAS-CHAVE}

Vasoespasmo. Hemodinâmica cerebral. Hemorragia subaracnoidea

\author{
ABSTRACT \\ Cerebral hemodynamic alterations due to vasospasm \\ understanding of the therapeutic procedures.

\section{KEY WORDS} \\ Vasospasm. Cerebral hemodynamic. Subarachnoid haemorrhage.
}

The authors describe the hemodynamic encephalic alterations that occur during the vasospasm after aneurysmal subarachnoid hemorrhage. The knowledge of these alterations promotes better

\section{Introdução}

Existem vários estudos na literatura que analisam de maneira isolada determinados componentes do hemometabolismo cerebral na vigência da isquemia por vasoespasmo. Tal isolamento experimental oculta o conhecimento fisiopatológico dinâmico que permite a integração e a análise crítica dos resultados oferecidos. No texto a seguir uma revisão compreensível das alterações perfusionais e metabólicas é realizada, permitindo o entendimento da questão. ${ }^{64}$

\section{Constrição arterial}

A constrição arterial bifásica que ocorre nas artérias relacionadas às cisternas intracranianas e a seus ramos diminui o fluxo sanguíneo encefálico (FSE) regional ou globalmente. ${ }^{17,18,50,67}$

Em relação à pressão de perfusão, esta permanece a mesma na entrada do segmento espástico, mas de- cresce rapidamente após esse segmento, diminuindo a pressão de perfusão a jusante. Essa diminuição da pressão de perfusão pode originar diminuição do fluxo sanguíneo. ${ }^{25,116}$

Havendo diminuição da pressão de perfusão e do fluxo, a arteríola pré-capilar se abre na entrada da microcirculação com o intuito inicial de diminuir a resistência vascular. Essa abertura da arteríola pré-capilar permite o aumento do volume sanguíneo encefálico, que se acumula no sistema de capacitância vascular constituído pela microcirculação, vênulas e veias. Assim, na vigência de vasoespasmo, o encéfalo tem baixo fluxo e alta volemia intrínseca e pode tornar-se tumefeito ou inchado. ${ }^{41,54,72,74,78,97}$

Embora o fluxo sanguíneo (em mL/100 g cérebro/ minuto) diminua proporcionalmente à estenose arterial, a velocidade do fluxo aumenta (em $\mathrm{cm} / \mathrm{segundo}$ ) de maneira inversamente proporcional, o que é diagnosticável ao exame por doppler transcraniano (DTC). 1,16,29,33,43,53,61,84,88,89,93,94 Se o FSE continua caindo, a extração tecidual de $\mathrm{O}_{2}$ (retirada de unidades de oxigênio por unidade de volume sanguíneo que trafega pela área em sofrimento) aumenta de maneira a manter

1. Instituto de Neurociências, São Paulo, SP

2. Serviço de Neurocirurgia Hospital Nove de Julho, São Paulo, SP. 
constante o consumo $\left(\mathrm{CMRO}_{2}\right.$ - cerebral metabolic rate of oxygen). Enquanto o aumento da extração compensar a diminuição do fluxo não há metabolismo anaeróbico ou acidose láctica. ${ }^{6,13,23,28,37,59,62,76,92,96,107}$ Quando o aumento da extração $\left(\mathrm{DAVO}_{2}\right.$ - diferença arteriovenosa de oxigênio) não compensar mais a queda de FSE, haverá isquemia e acidose láctica por metabolismo anaeróbico. Os neurônios estarão em penumbra isquêmica. ${ }^{6,13,45,48,60,109}$

$\mathrm{O}$ ácido $\left(\mathrm{H}^{+}\right)$é o principal vasodilatador da arteríola pré-capilar e o $\mathrm{pH}$ periarteriolar é o principal controlador da capacidade contrátil da arteríola pré-capilar, que constitui o mecanismo de autorregulação da circulação cerebral (MARCC). Nessa fase, uma vasodilatação que era miogênica, secundária à queda da pressão de perfusão encefálica (PPE), passa a ser metabólica, secundária à acidose láctica tecidual. ${ }^{8,57,66,98}$ Acidoses menores levam à paresia, ou vasodilatação apenas parética do MARCC. Acidoses maiores levam à plegia, ou vasodilatação máxima do MARCC, constituído pela capacidade contrátil da arteríola pré-capilar. ${ }^{57,66,98,99,106}$

Enquanto o sistema contrátil (MARCC) estiver normal ou parético, há resposta a variações da $\mathrm{PaCO}_{2}$. Quando o sistema arteriolar contrátil estiver plégico, não há mais resposta a variações da $\mathrm{PaCO}_{2}$. É difícil estudar as situações, pois em virtude de heterogeneidade do fluxo e do fenômeno da vulnerabilidade seletiva, as alterações são heterogêneas e as técnicas de estudo são globais, tornando os dados difíceis de serem estudados se não houver preciso conhecimento da fisiopatologia e da hemodinâmica situacionais. ${ }^{2,5,8,11,19,35,46,56,79,84}$

\section{Inchaço e edema}

Se o espasmo piora e não for revertido pela terapêutica hiperdinâmica, a acidose tecidual progressiva gerará intensa vasodilatação e aumento do volume sanguíneo encefálico (VSE). Esse desencadeamento da cascata vasodilatadora pode levar à hipertensão intracraniana (HIC) por hipervolemia cerebral (inchaço). ${ }^{4,25,80} \mathrm{~A}$ acidose tecidual progressiva também promove a cascata bioquímica e a lesão das membranas celulares e da barreira hematoencefálica, causando, respectivamente, os edemas citotóxico e vasogênico, que contribuem para o aumento da pressão intracraniana (PIC). ${ }^{14,27,63,83,90,95,108}$

\section{Reperfusão}

Após a resolução progressiva do espasmo ou a resposta às medidas de suporte hemodinâmico, o tecido cerebral é reperfundido.

No vasoespasmo considera-se que o sistema de resistência constituído pela capacidade contrátil da arteríola pré-capilar foi mudado para o local da resistência oferecida pela artéria espástica. Esse fenômeno é chamado de translocação a montante do sistema de resistência. ${ }^{21,24}$ Vencendo-se a resistência da artéria espástica a pressão de perfusão e o fluxo regional ou global serão transmitidos novamente diretamente à microcirculação, que estará dilatada pela acidose local e com pouca resistência. ${ }^{28,37,44,73}$

Assim, três situações subsequentes podem ocorrer na reperfusão.

Na primeira, uma hiperemia reativa e autolimitada ocorre, mantendo-se a velocidade do fluxo mais alta, enquanto houver baixa resistência. Os sistemas metabólico e hemodinâmico se compensam e há retorno à normalidade. A resposta às variações da $\mathrm{PaCO}_{2}$ que estava parcialmente prejudicada retorna ao normal. Espera-se que a reperfusão normalize os parâmetros hemometabólicos e diminua o VSE e a PIC por reverter a vasodilatação isquêmica. .11, $19,22,31,32,34,35$

Na segunda, a microcirculação se fechou definitivamente e não é possível reperfundir o tecido isquêmico (no reflow fenomenon). O fluxo e a velocidade de fluxo serão nulos. ${ }^{4,22,31,32,34,52}$

$\mathrm{Na}$ terceira, após a reperfusão, pode haver uma hiperemia inicial e depois seguir-se uma nova queda de fluxo (oligoêmica ou isquêmica) que pode resultar-se, sob o ponto de vista hemodinâmico ao aumento da PIC, ou sob o ponto de vista bioquímico ao acúmulo tecidual de tromboxano $\mathrm{A}_{2}$ gerado na isquemia. . $2,31,32,34,38,49,58,81,100$

\section{Instalação da hipertensão intracraniana}

A hipervolemia cerebral progressiva (inchaço) e o aumento de água tecidual e intracelular (edema) podem gerar o aumento progressivo da PIC até a ocorrência da HIC. ${ }^{87,103}$ Se a HIC for suficiente para decrescer a PPE e o FSE, haverá vasodilatação adicional por acidose e perda da resposta às variações da $\mathrm{PaCO}_{2}$. A velocidade de fluxo diminui pela queda da PPE e o índice de pulsatilidade aumentado indica que na sístole há maior entrada de sangue no crânio do que na sístole habitual sem HIC, e na diástole há menor entrada de sangue no crânio do que na diástole habitual sem HIC. Se o quadro 
progredir, o FSE e a velocidade de fluxo decrescem até a parada circulatória. ${ }^{26,53,94,105}$

Quando a HIC aumenta e a PPE e FSE diminuem há, novamente, aumento da $\mathrm{DAVO}_{2}$ e depois queda do $\mathrm{CMRO}_{2}$. Essa isquemia é induzida pela $\mathrm{HIC}$ e não pelo espasmo, embora as situações possam se associar. ${ }^{26}$

É interessante associar o fato de que logo após a ruptura do aneurisma há uma HIC aguda com queda da PPE e isquemia encefálica. A isquemia abre a arteríola pré-capilar, aumenta o VSE e causa inchaço que eleva adicionalmente a PIC. Alterações de FSE, VSE, $\mathrm{DAVO}_{2}$ e $\mathrm{CMRO}_{2}$ nessa fase relacionam-se à $\mathrm{HIC}$ e não ao espasmo, e sua interpretação tem relação com o estado hemodinâmico da HIC. ${ }^{28,30,65}$ Os pacientes com maior HIC inicial apresentam maiores sangramentos cisternais e maior ocorrência e gravidade de vasoespamo, e os fenômenos se sobrepõem, devendo ser interpretados à luz da fisiopatologia. ${ }^{104}$

\section{Terapêutica hemodinâmica}

A hemodiluição (melhora das propriedades reológicas) facilita o fluxo laminar na microcirculação e fornece $\mathrm{O}_{2}$ ao tecido. Entretanto, hemodiluições excessivas podem comprometer a capacidade de transportar $\mathrm{O}_{2}$ para o tecido e piorar a isquemia e a acidose. A monitorização da pressão tecidual de $\mathrm{O}_{2}$ e a microdiálise podem auxiliar nessa situação. É interessante notar que a hemodiluição aumenta de início a velocidade do fluxo, o que não significa piora do espasmo. . $^{3,9,71}$

A hipertensão arterial induzida aumenta a PPE e força a circulação através da área espástica, promovendo também, inicialmente, um aumento do fluxo e da velocidade do fluxo. ${ }^{7,10,20,47,55,68,70,75,77,85}$

Se a terapêutica hiperdinâmica funcionar, a reoxigenação tecidual devolve a capacidade contrátil da arteríola pré-capilar, a reatividade a variações da $\mathrm{PaCO}_{2}$ e diminui-se o volume sanguíneo cerebral à medida que melhora o FSE. A velocidade de fluxo inicialmente aumenta e depois se normaliza. ${ }^{7,10,20,34,42,69,102,110-114}$

A hipervolemia induzida é uma forma de aumentar o débito cardíaco (DC) e diluir o doente. São usadas sobrecargas volêmicas que otimizam o DC medido pelo cateter de Swan-Ganz, de modo que a pressão capilar pulmonar ótima não atinja níveis que causem hipertensão hidrostática pulmonar retrógrada e mesmo edema agudo de pulmão. ${ }^{7,12,39,40,51,82,86,91,101,111,115}$

O hiperdinamismo, que é o aumento artificialmente induzido do DC por sobrecarga volêmica e catecolaminas inotrópicas positivas, melhora a perfusão cerebral isquêmica. Embora pareça muito importante e relacionada à melhora dos pacientes, a medida do DC tem sido relegada a segundo plano nas pesquisas, talvez pelas controvérsias que envolvem o uso do cateter de Swan-Ganz. ${ }^{15,36}$

\section{Referências}

1. Aaslid R, Huber P, Nornes H. Evaluation of cerebrovascular spasm with transcranial Doppler ultrasound. J Neurosurg. 1984;60:37-41.

2. Ackerman $\mathrm{RH}$, Correia JA, Alpert NM. Positron imaging in ischemic stroke disease using compounds ladeled with oxygen 15. Initial results of clinicophysiologic correlations. Arch Neurol. 1982;38:537-43.

3. Adams MP. Prevention of brain ischemic after aneurismal subarachonoid hemorrahege. Neurol Clin. 1992;10:251-68.

4. Asano T, Sano K. Pathogenic role Fo no-reflow phenomenon in experimental subarachnoid hemorrhage in dogs. J Neurosurg. 1977;46:454-66.

5. Baker RP, Martin WRW, Herscovitch P. Evaluation by pósitron emission tomography of cerebral hemodynamics and metabolism following subarachnoid hemorrhage. J Nucl Med. 1982;23:5-9.

6. Baron JC, Rougemont D, Bousser MG. Local CBF, oxygen extraction fraction (OEF), and CMRO2: prognostic value in recent supratentorial infarction in humans. $\mathrm{J}$ Cereb Blood Flow Metab. 1983;3:31-41.

7. Batjer H: Comment on Yamakami I, Isobe K, Yamaura A. Effects on intravascular volume expansion on cerebral blood flow in patients with ruptured cerebral aneurysms. Neurosurgery. 1987;21:309.

8. Bayliss WM. On the local reactions of the arterial wall to changes of internal pressure. J Physiol. 1902;28:220-31.

9. Belli A, Sem J, Petzold A, Russo S. Kitchen N, Smith M. Metabolic failure precedes intracranial pressure rises in traumatic brain injury: a microdialysis study. Acta Neurochir (Wien). 2008;150:461-70.

10. Boisvert DP, Overton TR, Weir B. Cerebral arterial responses to induced hypertension following subarachnoid hemorrhage in the monkey. J Neurosurg. 1978;49:75-83.

11. Boisvert DPJ, Pickard JD, Graham DI. Delayed effects of subarachnoid hemorrhage on cerebral metabolism and the cerebrovascular response to hypercapnia in the primate. $J$ Neurol Neurosurg Psychiatry. 1979;42:892-8.

12. Bouma GJ, Muizelaar JP. Relationship between cardiac output and cerebral blood flow in patients with intact and with impaired autoregulation. J Neurosurg. 1990;73:368-74

13. Carpenter DA, Grubb Jr. RL, Tempel LW, Powers WJ. Cerebral oxygen metabolism after aneurysms subarachnoid hemorrhage. J Cereb Blood Flow Metab. 1991;11:837-44.

14. Crompton MR. The pathogenesis of cerebral infarction following the rupture of cerebral Berry aneurysms. Brain. 1964;87:491-510.

15. Davis DH, Sundt Jr. TM. Relationship of cerebral blood flow to cardiac output, mean arterial pressure, blood volume, and alpha and beta blockade in cats. J Neurosurg. 1980; 52:745-754.

16. Davis SM, Andrews JT, Lichtenstein M, Rossiter SC, Kaye $\mathrm{AH}$, Hopper J. Correlations between cerebral arterial velocities, blood flow, and delayed cerebral ischemia after subarachnoid hemorrhage. Stroke. 1992;23:492-7. 
17. Diringer MN, Heffez DS, Monsein L, Kirsch JR, Hanley DF, Traystman RJ. Cerebrovascular $\mathrm{CO}_{2}$ reactivity during delayed vasospasm in a canine model of subarachnoid hemorrhage. Stroke. 1991;22:367-72.

18. Du Boulay G, Symon L, Ackerman RH. The reactivity of the spastic arteries. Neuroradiology. 1973;5:37-47.

19. Enevoldsen EM, Jensen FT. Autoregulation and CO2 responses of cerebral blood flow in patients with acute severe head injury. J Neurosurg. 1978;48:689-703.

20. Farrar JK, Gamache FW, Ferguson GG. Effects on profound hypertension on cerebral blood flow during surgery for intracranial aneurysms. J Neurosurg. 1981;55:857-64.

21. Fein JM, Boulos R. Local cerebral blood flow in experimental middle cerebral artery vasospasm. J Neurosurg. 1973;39:337-47.

22. Fein JM. Brain energetics and circulatory control after subarachnoid hemorrhage. J Neurosurg. 1976;45:498-507.

23. Ferguson GG, Harper AM, Fitch W. Cerebral blood flow measurements after spontaneous subarachnoid hemorrhage. Eur Neurol. 1972;8:15-22.

24. Findlay JM, Weir BKA, Kanamaru K. Arterial wall changes in cerebral vasospasm. Neurosurgery. 1989;25:736-746.

25. Finnerty Jr. FA, Witkin L, Fazekas JF. Cerebral hemodynamics during cerebral ischemia induced by acute hypotension. J Clin Invest. 1954;33:1227-32.

26. Fukuhara T, Douville CM, Eliott JP, Newell DW, Winn HR. Relationship between intracranial pressure and the development of vasospasm after aneurysmal subarachnoid hemorrhage. Neurol Med Chir (Tokyo). 1998;38:710-17.

27. Garcia JH, Mitchem HL, Briggs L. Transient focal ischemia in subhuman primates. Neuronal injury as a function of local cerebral blood flow. J Neuropathol Exp Neurol. 1983;42: 44-60.

28. Gelmers HJ, Beks JWF, Journée HL. Regional cerebral blood flow in patients with subarachnoid hemorrhage. Acta Neurochir (Wien). 1979;47:245-51.

29. Grosset DG, Straiton J, McDonald I, Cockburn M, Bullock R. Use of transcranial Doppler sonography to predict development of a delayed schemic déficit after subarachnoid hemorrhage. J Neurosurg. 1993;78:183-7.

30. Grubb Jr. RL, Raichle ME, Eichling JO. Effects of subarachnoid hemorrhage on cerebral blood volume, blood flow, and oxygen utilization in humans. J Neurosurg. 1977;46:446-53

31. Handa $\mathrm{Y}$, Hayashi M, Takeuchi H, Kubota T, Kobayashi $\mathrm{H}$, Kawano $\mathrm{H}$. Time course of impairment of cerebral autoregulation during chronic cerebral vasospasm after subarachnoid hemorrhage in primates. J Neurosurg. 1992;76:493-501.

32. Handa $Y$, Kabuto M, Kobayashi $H$. The correlation between immunological reaction in the arterial wall and the time course of the development of cerebral vasospasm in a primate model. Neurosurgery. 1991;28:542-9.

33. Harders AG, Gilsbach JM. Time course of blood velocity changes related to vasospasm in the circle of Willis measured by transcranial Doppler ultrasound. J Neurosurg . 1987;66:718-28.

34. Hashi K, Meyer JS, Shinmaru S. Cerebral hemodynamic and metabolic changes after experimental subarachnoid hemorrhage. J Neurol Sci. 1972;17:1-14.

35. Hashi K, Meyer JS, Shinmaru S. Changes in cerebral vasomotor reactivity to $\mathrm{CO} 2$ and autoregulation following experimental subarachnoid hemorrhage. J Neurol Sci. 1972;17:15-22.

36. Hashimoto M, Yamachita J, Koide K, Ikeda K, Higashi $\mathrm{S}$. Extreme hemodilution may be harmful in patients with symptomatic vasospasm after subarachnoid hemorrhage. In: Sano K, Takakura K, Kassel NF, Sasaki T (Eds.). Cerebral vasospasm. Tokyo: University of Tokyo Press, 1990. p.350-1.

37. Heilbrun MP, Olesen J, Lassen NA. Regional cerebral blood flow studies in subarachnoid hemorrhage. J Neurosurg. 1972;37:36-44.

38. Heiss WD, Rosner G. Functional recovery of cortical neurons as related to degree and duration of ischemia. Ann Neurol. 1983;14:294-301.

39. Henriksen L, Paulson OB, Smith RJ. Cerebral blood flow following normovolemic hemodilution in patients with high hematocrit. Ann Neurol. 1981;9:454-7.

40. Heros RC, Korosue K. Hemodilution for cerebral ischemia. Stroke. 1989;20:423-7.

41. Hino A, Mizukawa N, Tenjin H. Postoperative hemodynamic and metabolic changes in patients with subarachnoid hemorrhage. Stroke. 1989;20:1504-10.

42. Hyodo A, Heros RC, Tu YK. Acute effects of isovolemic hemodilution with crystalloids in a canine model of focal cerebral ischemia. Stroke. 1989;20:534-40.

43. Hutchinson K, Weir B. Transcranial Doppler studies in aneurysm patients. Can J Neurol Sci. 1989;16:411-6.

44. Ishii R. Regional cerebral blood flow in patients with ruptured intracranial aneurysms. J Neurosurg. 1979:50:587-94.

45. Jaeger M, Schuhmann MU, Soehle M, Nagel C, Meixensberger J. Continuous monitoring of cerebrovascular autoregulation after subarachnoid hemorrhage by brain tissue oxygen pressure reactivity and its relation to delayed cerebral infarction. Stroke. 2007;38:981-6.

46. Jakubowski J, Bell BA, Symon L, Zawirski MB, Francis DM. A primate model of subarachnoid hemorrhage: change in regional cerebral blood flow, autoregulation, carbon dioxide reactivity, and central conduction time. Stroke. 1982;13: 601-11.

47. James IM. Changes in cerebral blood flow and in systemic arterial pressure following spontaneous subarachnoid hemorrhage. Clin Sci. 1968;35:11-22.

48. Jones TH, Morawetz RB, Crowell RM, Marcoux FW, FitzGibbon SJ, DeGirolami U, et al. Thresholds of focal cerebral ischemia in awake monkeys. J Neurosurg. 1981;54:773-82.

49. Juvela S. Cerebral infarction and release of platelet thromboxane after subarachnoid hemorrhage. Neurosurgery. 1990;27:929-35.

50. Kamiya K, Kuyama H, Symon L. An experimental study of the acute stage of subarachnoid hemorrhage. J Neurosurg. 1983;59:917-24.

51. Kassel NF, Peerless SJ, Durward QJ, Beck Dw, Drake CG Adams HP. Treatment of ischemic deficits from vasospasm with intravascular volume expansion and induced arterial hypertension. Neurosurgery. 1982;11:337-43.

52. Kelly PJ, Gorten RJ, Grossman RG, Eisenberg HM. Cerebral perfusion, vascular spasm, and outcome in patients with ruptures intracranial aneurysms. J Neurosurg. 1977;47:44-9.

53. Klingelhofer J, Dander D, Holzgraefe M, Bischoff C, Conrad B. Cerebral vasospasm evaluated by transcranial Doppler ultrasonography at different intracranial pressures. J Neurosurg. 1991;75:752-8.

54. Koike T, Ishii R, Ihara I. Cerebral cirulation and metabolism in patients with ruptured aneurysms - with special reference to vasospasm and infarction. J Cereb Blood Flow Metab. 1981;1:S522-S523.

55. Kosnik EJ, Hunt WE. Postoperative hypertension in the management of patients with intracranial arterial aneurysms. J Neurosurg. 1976;45:148-54. 
56. Kutsukawa T, Takahashi S, Saito C. Studies of cerebral hemodynamics in subarachnoid hemorrhage. Tohoku J Exp Med. 1968;94:415-7.

57. Langfitt TW, Weinstein JD, Kassel NF. Cerebral vasomotor paralysis produced by intracranial hypertension. Neurology. 1965;15:622-41.

58. Lassen NA. Cerebral blood flow and oxygen consumption in man. Physiol Rev. 1959;39:183-238.

59. Lassen NA. The luxury-perfusion syndrome and its possible relation to acute metabolic acidosis localised within the brain. Lancet. 1966;2:1113-5.

60. Lassen NA, Lane MH. Validity of internal jugular blood for study of cerebral blood flow and metabolism. J Appl Physiol. 1961;16:313-20.

61. Laumer R, Steinmeier R, Gonner F, Vogtmann T, Priem $\mathrm{R}$, Fahlbusch R. Cerebral hemodynamics in subarachnoid hemorrhage evaluated by transcranial Doppler sonography. Part 1. Reliability of flow velocities in clinical management. Neurosurgery. 1993;33:1-9.

62. Lenzi GL, Frackowiak RS, Jones T. Cerebral oxygen metabolism and blood flow in human cerebral ischemic infarction. J Cereb Blood Flow Metab. 1982;2:321-35.

63. Macdonald RL. Cerebral vasospasm. Neurosurg Quarterly. 1995;5:73-97.

64. Macdonald RL, Weir BKA. Free radicals and cerebral vasospasm. Free Rad Biol Med. 1994;16:633-44.

65. Martin WRW, Baker RP, Grubb RL, Raichle ME. Cerebral blood volume, blood flow, oxygen metabolism in cerebral ischemia and subarachnoid hemorrhage: an in-vivo study using positron emission tomography. Acta Neurochir (Wien). 1984;70:3-9.

66. Mendelow AD, McCalden TA, Hattingh J, Rosendorff C, Eidelman BH. Cerebrovascular reactivity and metabolism after subarachnoid hemorrhage in baboons. Stroke. 1981; 12:58-65.

67. Mickey B, Vorstrup S, Voldby B, Lindewald H, Harmsen A, Lassen NA. Serial measurement of regional cerebral blood flow in patients with SAH using 133Xe inhalation and emission computerized tomography. J Neurosurg. 1984;60:916-22.

68. Montgomery EG, Grubt RL, Raichle ME. Cerebral hemodynamics and metabolism in postoperative cerebral vasospasm and treatment with hypertensive therapy. Ann Neurol. 1981;3:502-6.

69. Muizelaar JP, Wei EP, Kontos HA, Becker DP. Cerebral blood flow is regulated by changes in blood pressure and in blood viscosity alike. Stroke. 1986;17:44-8.

70. Nagel A, Fraetz D, Schiwk T, Frieler K, Sakowitz O, Vajkoczy $P$, Sarnafazdeh A. Relevance of intracranial hypertension for cerebral metabolism in aneurismal subarachnoid hemorrhage. J Neurosurg. 2009;111:94-101.

71. Nilsson OG, Brandt L, Ungerstedt U, Saveland H Bedside detection of brain ischemia using intracerebral microdialysis: subarachnoid hemorrhage and delayed ischemic deterioration. Neurosurgery. 1999;45:1176-85.

72. Nornes H, Knutzen HB, Wikeby P. Cerebral arterial blood flow and aneurysm surgery. Part 2: Induced hypotension and autoregulatory capacity. J Neurosurg. 1977;47:819-27.

73. Olesen J, Paulson OB, Lassen NA. Regional cerebral blood flow in man determined by the initial slope of the clearance of intra-arterially injected 133Xe. Theory of the method, normal values, error measurement, correction for remaining radioactivity, relation to other flow parameters and response to PaCO2 changes. Stroke. 1971;2:519-40.

74. Olsen TS, Larsen B, Skriver EB, Herning M, Enevoldsen $\mathrm{E}$, Lassen NA. Focal cerebral hyperemia in acute stroke.
Incidence, pathophysiology and clinical significance. Stroke. 1981;12:598-607.

75. Origitano TC, Wascher TM, Reichman $\mathrm{OH}$ and Anderson DE. Sustained increased cerebral blood flow with prophylactic hypertensive hypervolemic hemodilution after subarachnoid hemorrhage. Neurosurgery. 1990;27:729-40.

76. Paulson OB. Regional cerebral blood flow in apoplexy due to occlusion of the middle cerebral artery. Neurology. 1970;20:63-77.

77. Peterson EW, Cardoso ER. The blood-brain barrier following experimental subarachonoid hemorrhage. Part 1: Response to insult caused by arterial hypertension. J Neurosurg. 1983;58:338-44.

78. Petruk KC, West GR, Marriott MR, McIntyre JW, Overtone TR, Weir BKA. Cerebral Blood flow following induced subarachnoid hemorrhage in the monkey. J Neurosurg. 1972;37:316-24.

79. Petruk KC, Weir BKA, Overton TR Marriott MR, Grace $M G$. The effect of graded hypocapnia and hypercapnia on regional cerebral blood flow and cerebral vessel caliber in the rhesus monkey: study of cerebral hemodynamics following subarachnoid hemorrhage and traumatic internal carotid spasm. Stroke. 1974;5:230-6.

80. Powers WJ, Grubb Jr. RL, Raichle ME. Physiologic responses to focal cerebral ischemia in humans. Ann Neurol. 1984;16:546-52.

81. Powers WJ, Grubb RL, Baker RP, Mintun MA, Raichle ME. Regional cerebral blood frow and metabolism in reversible ischemia due to vasospasm. J Neurosurg. 1985;62:539-46.

82. Pritz MB, Giannotta SL, Kindt GW, McGillicuddy JE, Prager RL. Treatment of patients with neurological déficits associated with cerebral vasospasm by intravascular volume expansion. Neurosurgery. 1978;3:364-8.

83. Raichle ME. The pathophysiology of brain ischemia. Ann Neurol. 1983;13:2-10.

84. Romner B, Brandt L, Berntman L, Algotsson L, Ljunggren B, Messeter K. Simultaneous transcranial Doppler sonography and cerebral blood flow measurements of cerebrovascular CO2-reactivity in patients with aneurysmal subarachnoid haemorrhage. Br J Neurosurg. 1991;5:31-7.

85. Rosenwasser RH, Delgado TE, Buchheit WA, Freed MH. Control of hypertension and prophylaxis against vasospasm in cases of subarachonoid hemorrhage: a preliminary report. Neurosurgery. 1983;12:658-61.

86. Shimoda M, Oda S, Tsugane R, Sato O. Intracranial complications of hypervolemic therapy in patients with a delayed ischemic deficit attributed to vasospasm. J Neurosurg. 1993;78:423-9.

87. Schirmer CM, Hoit DA, Malek AM. Decompressive hemicraniectomy for the treatment of intractable intracranial hypertension after aneurysmal subarachnoid hemorrhage. Stroke. 2007;38:987-92

88. Seiler RW, Grolimund P, Aaslid R, Huber P, Nornes H. Cerebral vasospasm evaluated by transcranial ultrasound with clinical grade ant CT-visualized subarachnoid hemorrhage. J Neurosurg. 1986;64:594-600.

89. Sekhar LN, Wechsler LR, Yonas H, Luyckx K, Obrist W. Value of transcranial Doppler examination in the diagnosis of cerebral vasospasm after subarachnoid hemorrhage. Neurosurgery. 1988;22:813-21.

90. Shigeno T, Fritschka E, Brock M, Schramm J, Shigeno S Cervós-Navarro J. Cerebral edema following experimental subarachnoid hemorrhage. Stroke. 1982;13:367-79.

91. Shimoda M, Oda S, Tsuganc R, Sato O. Intracranial complications of hypervolemic therapy in patients with 
a delayed ischemic déficit attributed to vasospasm. J Neurosurg. 1993;78:423-9.

92. Simeone FA, Trepper PJ, Brown DJ. Cerebral blood flow evaluation of prolonged experimental vasospasm. J Neurosurg. 1972;37:302-311.

93. Sloan MA, Haley Jr. EC, Kassel NF, Henry ML, Stewart SR, Beskin RR et al. Sensitivity and specificity of transcranial doppler ultrasonography in the diagnosis of vasospasm following subarachnoid hemorrhage. Neurology. 1989;39:1514-8

94. Steinmeier R, Laumer R, Bondar 1, Priem R, Fahlbusch R. Cerebral hemodynamics in subarachnoid hemorrhage evaluated by transcranial Doppler sonography. Part 2. Pulsatility indicies: normal reference e values and characteristics in subarachnoid hemorrhage. Neurosurgery. 1993;33:10-8.

95. Sugi T, Fujishima M, Omae T. Lactate and pyruvate concentrations, and acid-base balance of cerebrospinal fluid in experimentally induced intracerebral and subarachnoid hemorrhage in dogs. Stroke. 1975;6:715-9.

96. Symon L, Ackerman R, Bull JW, Du Boulay EP, Marshall $\mathrm{J}$, Rees JE, et al. The use of the xenon clearance method in subarachnoid hemorrhage. Post-operative studies with clinical and angiographic correlation. Eur Neurol. 1972;8:814.

97. Symon L. Disordered cerebro-vascular physiology in aneurysmal subarachnoid hemorrhage. Acta Neurochir (Wien). 1978;41:7-22.

98. Takeuchi $\mathrm{H}$, Handa $\mathrm{Y}$, Kobayashi $\mathrm{H}$, Kawano H, Hosotani K, Hayashi M. Impairment of cerebral autoregulation during the development of chronic cerebral vasospasm after subarachnoid hemorrhage in primates. Neurosurgery. 1991;28:41-8.

99. Terada T, Kikuchi H, Karasawa J, Kuriyama Y. Sequential changes in the autoregulation of cerebral blood flow in patients with vasospasm. Neurol Med Chir (Tokyo). 1985;25:89-94.

100. Terada T, Koma N, Mayashi S, Moriwaki M, Hyoltani G, Uematsu $Y$, et al. Hemorrhage in fraction after cerebral aneurysm. Neurosurgery. 1986;18:415-8.

101. Pritz MB, Giannotta SL, Kindt GW, McGillicuddy JE, Prager RL. Treatment of patients with neurological deficits associated with cerebral vasospasm by intravascular volume expansion. Neurosurgery. 1978;3:367-70.

102. Tu YK, Heros R, Karacostas D, Liszczak T Hyodo A, Candia $G$, et al. Isovolemic hemodilution in experimental focal cerebral ischemia. Part 2: Effects on regional cerebral blood flow and size of infarction. J Neurosurg. 1988;69:82-91.

103. Voldby B, Enevoldsen EM. Intracranial pressure changes following aneurysm rupture. Part 2: Associated cerebrospinal fluid lactacidosis. J Neurosurg. 1982;56:197-204.

104. Voldby B, Enevoldsen EM. Intracranial pressure changes following aneurysm rupture. Part 3: Recurrent hemorrhage. J Neurosurg. 1982;56:784-9.
105. Voldby B, Enevoldsen EM, Jensew FT. Regional CBF, intraventricular pressure and cerebral metabolism in patients with ruptured intracranial aneurysms. J Neurosurg. 1958;62:48-58

106. Voldby B, Enevoldsen EM, Jensen FT. Cerebro vascular reactivity in patients with suptured intracranial aneurysms. J Neurosurg. 1985;62:59-67.

107. Weir B, Menon D, Overton T. Regional cerebral blood flow in patients with aneurysms: estimation by Xenon 133 inhalation. Can J Neurol Sci. 1978;5:301-5.

108. Williams SK, Matthews MA Wagner RC. Metabolic studies on the micropinocytic process in endothelial cells. Microvasc Res. 1979;18:175-84.

109. Wise RJ, Bernardi S, Frackowiak RS, Legg NJ, Jones T. Serial observations on the pathophysiology of acute stroke. The transition from ischemia to infarction as reflected in regional oxygen extraction. Brain. 1983;106:197-222.

110. Wood JH, Polyzoidis KS, Epstein CM. Improvement in cerebral blood flow and Power spectral EEG after isovolemic hemodilution in stroke patients. J Cereb Blood Flow Metab. 1983;3:558-89.

111. Wood JH, Simeone FA, Fink EA, Golden MA. Hypervolemic hemodilution of cardiac output, regional cortical blood flow, and ICP after intravascular volume expansion with low molecular weight dextran. J Neurosurg. 1983;59:500-9.

112. Wood JH, Simeone FA, Kron RE, Litt M. Rheological aspects of experimental hypervolemic hemodilution with low molecular weight dextran: relationships of cortical blood flow, cardiac output, and intracranial pressure to fresh blood viscosity and plasma volume. Neurosurgery. 1982;11: 739-53.

113. Wood JH, Simeone FA, Snyder LL. Cortical oxygen transport during hypervolemic hemodilutional therapy for focal cerebral ischemia. Neurosurgery. 1982;10:781-8.

114. Wood JH, Simeone FA, Kron RE, Snyder LL. Experimental hypervolemic hemodilution: physiological correlations of cortical blood flow, cardiac output, and intracranial pressure with fresh blood viscosity and plasma volume. Neurosurgery. 1984;14:709-23.

115. Yamakami I, Isobe K, Yamaura A. Effects to intravascular volume expansion on cerebral blood flow in patients with ruptured cerebral aneurysms. Neurosurgery. 1987;21:303-9.

116. Zingesser LH, Schechter MM, Dexter J, Katzman R, Scheinberg LC. On the significance of spasm Associated with rupture of a cerebral aneurysm. The relationship between spasm as noted angiographically and regional blood flow determinations. Arch Neurol. 1968;18:520-8.

Endereço para correspondência Marcos Augusto Stávale Joaquim Alameda Campinas, $1.360,16^{\circ}$ andar 01404-002 - São Paulo, SP

Email: marcos.stavale@terra.com.br 